\title{
Selected Reference Books of 1989-90
}

\section{Eileen McIlvaine}

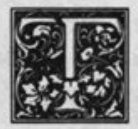

his article follows the pattern set by the semiannual series initiated by the late Constance $\mathrm{M}$. Winchell more than thirty years ago and continued by Eugene Sheehy. Because the purpose of the list is to present a selection of recent scholarly and general works of interest to reference workers in university libraries, it does not pretend to be either well balanced or comprehensive. A brief roundup of new editions of standard works is provided at the end of the article. Code numbers (such as AD540, CJ331) have been used to refer to titles in Guide to Reference Books, 10th ed. (Chicago: American Library Association,1986).

\section{PHILOSOPHY}

Dictionnaire des Philosophes Antiques. Richard Goulet, ed. Paris: Centre National de la Recherche Scientifique, 1989. In progress. Contents: v.1, $\mathrm{Abam}(\mathrm{m})$ on à Axiothéa. $838 \mathrm{p} .425 \mathrm{~F}$ (ISBN 2-222-04042-6).

This comprehensive biographical dictionary will prove useful, even to librarians and scholars who lack French for its numerous bibliographic references to both ancient and modern sources. Covering primarily Greek philosophers from the earliest times to roughly the sixth century, the signed essays in this first volume range from a paragraph to more than 150 pages (for Aristotle) in length. Most entries contain birth and death dates, if known, citations to articles in Pauly-Wissowa (Guide DA126), biographical sketches with references to further primary and secondary sources, lists of works with manuscript and textual traditions and recommended or standard editions and translations, and a discussion of the subject's philosophical thought and influence. Longer entries tend to be arranged in outline form, though there is a great deal of variation in style and organization in articles by different contributors.

A notable feature of volume one is the lengthy appendix, which discusses the situation, history, archaeology, religious and philosophical significance, and personalities associated with the Academy in Athens, complete with some maps and illustrations. The volume concludes with name, keyword, and Greek keyword indexes. Recommended for all libraries with extensive collections in classics or philosophy.-B.J.

\section{SEMIOTICS}

Nöth, Winfried. Handbook of Semiotics. Advances in Semiotics. Bloomington:

Eileen Mcllvaine is head of Reference, Butler Library, Columbia University, New York, New York 10027. Although it appears under a byline, this list is a project of the reference departments of Columbia University Libraries, and notes are signed with the initials of these individual staff members: Barbara Sykes-Austin, Avery Library; James L. Coen, Business Library; Mary Cargill, Beth Juhl, Anita Lowry, Robert H. Scott, Sarah Spurgin, Junko Stuveras, Butler Library; Diane K. Goon, Barbara Kemp, Lehman Library. 
Indiana Univ. Pr., 1990. 576p. $\$ 57.50$ (ISBN 0-253-34120-5). LC 89-45199.

This is a "totally reworked, updated, and largely expanded" (p. x) edition of the author's Handbuch der Semiotik (Stuttgart: Metzler, 1985). And unlike some works that begin life in another language, this handbook is written with an admirable clarity and conciseness that greatly enhance its usefulness as a guide to the concepts, schools, terminology, authors, and literature of semiotics. Its approach is encyclopedic and pluralistic, covering both "theoretical and applied semiotics and [extending] from zoosemiotics to anthroposemiotics, including the various branches of cultural and text semiotics" (p. 4).

The arrangement is not alphabetical like a dictionary, but conceptual. There are eight chapters, each divided topically into numbered sections and subsections: History and Classics of Modern Semiotics; Sign and Meaning; Semiosis, Code, and the Semiotic Field; Language and Language-Based Codes; From Structuralism to Text Semiotics Schools and Major Figures; Text Semiotics: The Field; Nonverbal Communication; Aesthetics and Visual Communication. The text combines explanation and discussion with a survey of the literature. Plentiful in-text references guide the reader to key writings on each point, and the seventypage bibliography of cited works is a valuable guide to the literature itself. The extensive subject and name indexes, as well as the handsome layout and design, further aid the users of this book, whether they be students grappling for the first time with complex topics in semiotics or scholars seeking a survey of ideas or literature outside their particular field of expertise.-A.L.

\section{ENGLISH LITERATURE}

Marcuse, Michael J. A Reference Guide for English Studies. Berkeley: Univ. Calif. Pr., 1990. 790p. $\$ 100$ (ISBN 0-52005161-0). LC 86-14675.

Harner, James L. Literary Research Guide: A Guide to Reference Sources for the Study of Literatures in English and Related Topics. New York: Modern Lan- guage Assoc., 1989. 737p. \$35 (ISBN 0-87352-182-X). LC 89-12409.

A Reference Guide for English Studies is a comprehensive and impressive guide to English and American literature which includes a considerable amount of information not usually found in guides to English literature: lists of national bibliographies and library catalogs; sections addressing classical and modern literatures; and a chapter devoted to history and ancillae which describes 123 reference works in British and American history, geography, and chronologies, and numerous secondary works.

Physically, it resembles a Guide to Reference Books with longer annotations and smaller type. Twenty-four chapters address topics ranging from literature by country, period and genre, to professional topics, bibliography, biography, serials, and archives and manuscripts. Within each chapter, reference works are grouped by topic, and followed by lists of periodicals and "frequently recommended works." The descriptive annotations are well written, and nearly all cite additional works. Coverage is through 1985, with some additional titles from 1986 and 1987; the sections of recommended works, although valuable, suffer from being five years out of date.

The Literary Research Guide is more narrowly confined to English literature and is intended to replace Margaret Patterson's Literary Research Guide (Guide BD360). It does not give a cut-off date, although I could not find anything here which was not included above. It is complete and well written and suffers only in comparison to the Reference Guide for English Studies, which is so inspiring that I think readers will want to begin their research on the spot.-S.S.

\section{LATIN AMERICAN LITERATURE}

Forster, Merlin H. and K. David Jackson. Vanguardism in Latin American Literature: An Annotated Bibliographical Guide. Bibliographies and Indexes in World Literature, no. 27. New York: 
Greenwood, 1990. 214p. \$37.95 (ISBN 0-313-24861-3). LC 90-34103.

Although one of the contributing factors to the burst of Latin American creative writing in the 1950 s and 1960 s, the avant-garde writers of the 1920 s and 1930s have usually been regarded as minor figures. The compilers of this bibliography, both professors of Latin American literature, hope to make these writers more widely known. Based primarily on the holdings of the Benson Latin American Collection of the University of Texas at Austin, this is "an annotated guide to research materials rather than an exhaustive listing of everything ever written by and about Latin American vanguardists" (Intro.). It lists primary material from 1920 through 1935 and secondary material from 1920 to the mid-1980s.

Part $I$ is an introduction to vanguardism in Latin America. The actual bibliography is divided into two sections: the General List, "an annotated gathering of critical and bibliographic materials that documents and supports the multinational approach;" and the National Lists, arranged by country, which provide "categorized information on vanguardist groups, major figures, individual works, and literary journals." This should be an essential purchase for any library with an interest in Latin American literature.-M.C.

\section{Wilson, Jason. An A to $\mathrm{Z}$ of Modern Latin} American Literature in English Translation. London: Institute of Latin American Studies, 1989. 95p. $£ 7.50$ (ISBN O-901145-67-X).

This guide, compiled by a member of the Spanish Department of the University of London, will make identifying English translations of Latin American literature much easier. Arranged alphabetically by author, the guide lists translations of 256 nineteenth- and twentieth-century Latin American writers through mid-1989. The brief entries provide the English title, translator, publisher, and date of the translation. The original titles and dates are also provided, a welcome bonus to anyone who has used Index Tranlationum. The compiler has also included a useful list of anthologies of Latin American literature in English translation.

This guide could, however, be improved. There are no indexes, so the user must know the author. Poems, essays, and plays in collections are not analyzed. The arrangement of entries under each author is chronological by date of translation which can make finding a specific title by a prolific author somewhat difficult. Yet this is still an extremely useful source in any library where students ask for translations.M.C.

\section{CINEMA}

Armstrong, Richard B., and Mary Willems Armstrong. The Movie List Book: A Reference Guide to Film Themes, Settings and Series. Jefferson, N.C.: McFarland, 1990. 377p. \$29.95 (ISBN 0-89950-240-7). LC 89-43692.

Where else could you find lists of films about the "Abominable Snowman" (see also "Bigfoot"), about "Zombies," and on almost any imaginable topic in between, from the sublime ("Angels") to the ridiculous ("Pinball/VideoGames")? Or how about films featuring particular characters (Nancy Drew, or Robin Hood) or types of characters (composers, pirates, multiple personalities, or horses)? Maybe you are looking for films set on an island, in a prison, or on the subway (see also "Trains")? Or a film with the secret of "Eternal Youth," or one addressing serious concerns like "Drug Addiction" or "Suicide"?

The list of films under each heading is admittedly very selective and limited primarily to English-language feature films from the 1950s through the 1980s; the American Film Institute Catalog of Motion Pictures (Guide BG200), with its extensive subject/motif index, will be much more complete when it is finally finished. But this book is one of the few available sources for people who want to find fiction films "about" something, a query that comes not only from film buffs and trivia fans, but also from film students and scholars interpreting cul- 
tural phenomena through their expression in the movies. And, yes, there is an entry for "Librarians," with a list of films and a short commentary in which the authors wryly observe that in spite of exceptions that prove the rule-like Betty Davis' feisty portrayal of "a librarian fired for her refusal to censor a book on communism in the 1956 Storm Center-"it has been difficult for movie librarians to move away from their stereotyped image as shy, conservative bookworms" (p.205). The book could have used a proof reader; Storm Center is listed once with the date 1956 (correct) and once with the date 1955 in a single entry.-A.L.

\section{ART AND ARCHITECTURE}

\section{Art \& Architecture Thesaurus. Toni} Petersen, director. New York: Published on behalf of the J. Paul Getty Trust by Oxford Univ. Pr., 1990. 3v. $\$ 250$ (ISBN 0-19-5064038/set). LC 8926479.

The long-awaited publication in printed and electronic formats of the Art $\mathcal{E}$ Architecture Thesaurus is the culmination of a ten-year project to organize and disseminate a standard, controlled vocabulary for the fields of art and architecture. Modeled on the National Library of Medicine's MeSH thesaurus and prepared according to ANSI and BSI standards, this comprehensive and authoritative reference source, when consistently applied to catalogs and databases of bibliographic and visual materials, will enable its intended users-libraries, museums, archives, historical and other special collections, abstracting and indexing services, and scholars (who have also been its collaborators and contributors)-to "bring about the most comprehensive retrieval of information possible on a particular topic by linking terms whose meanings are related" (v.1, p.4). The AAT, as it is known, will, when completed, encompass the full spectrum of terminology for art and architecture of the Western world from the ancient period to the present day.
The printed format has been issued in three volumes comprising 47,000 terms in twenty-three of the projected forty hierarchies (conceptually ordered arrangements showing broader and narrower relationships). The hierarchies are themselves grouped under seven major areas or facets which constitute subdivisions of the terminology. These facets include: Associated Concepts (such as scientific, religious, and artistic concepts); Physical Attributes (shapes, colors, sizes, etc.); Styles and Periods; Agents (people and organizations); Activities (including the disciplines in the humanities, social sciences and "hard" sciences, functions, such as expertizing, events such as ceremonies, and processes or techniques, such as sketching, printing, or bookbinding); Materials (brick, tile, wood, etc.); and Objects both in the built environment, such as furnishings and equipment, and as forms of visual and verbal communication (e.g., drawings, photographs, and written document types). These are fully displayed in volume 1 by the aid of a thumb index for quick reference.

Each of the hierarchies within the facets is introduced with a description of its scope, organization, relation to other hierarchies, descriptor form and use, and the number of descriptors and has been given a two-character code further subdivided numerically to clarify its relationship within the hierarchy. In volumes 2 and 3 the terms are arranged alphabetically using standard thesaurus conventions to link alternate and lead-in terms, provide source and scope notes, classification codes, and hierarchy line number. A lengthy "History of the AAT," along with a description of the project, a user's guide, and a comprehensive list of sources are also provided in volume 1 . All give clear evidence of the wide range of scholarly expertise and careful attention to the design, construction, and intellectual integrity of this critical and much-needed codification of the "rich and uncontrolled, that is to say, inconsistent" vocabulary of the arts (v.1, p.3).

The three-volume printed set and electronic edition of the AAT (available on 
floppy disks and appearing simultaneously as an authority file in RLIN) are the first published releases of the ongoing $A A T$ project, which is an operating unit of the J. Paul Getty Trust's Art History Information Program (AHIP). Seventeen additional hierarchies are under development and will be published on a regular basis by Oxford University Press as supplementary volumes, which will also include new terms and changes to the existing volumes. "Completion of all projected hierarchies is anticipated within the next few years, and a new edition will then be released that includes the entire set" (v.1, p.21).-B.S.-A.

\section{POPULAR CULTURE}

Historical Dictionary of World's Fairs and Expositions, 1851-1988. John E. Findling, ed. New York: Greenwood, 1990. 443p. \$75 (ISBN 0-313-26023-0). LC 89-17217.

Despite the financial difficulties of recent events such as the New Orleans Louisiana World Exposition (1984), the world's fair continues to provide a fascinating mix of commerce and commercialism, rampant nationalism and international understanding, high art and incredible kitsch. With fairs planned for the Columbus quincentennial in both Genoa and Seville, the international exposition remains quite a robust form of entertainment, enlightenment, and boosterism. This dictionary pulls together information on ninety-six exhibitions for the historians and students of architecture, art, technology, industry, or popular culture.

The fairs, beginning with the Great London Exhibition in 1851, are described in signed chapters arranged in chronological order. Each chapter details the planning, financial opportunities and reverses, local and national government involvement, architecture and attractions, international participation, and local and worldwide legacies of the fairs, complete with bibliographies and a few illustrations. Appendixes include a description of the governing Bureau of International Expositions, tables of fair statistics, and lists of fair officials, smaller fairs not included in the chapters, fairs which were planned but not put on, and forthcoming fairs. A general bibiliography discusses works which deal with the nature and history of fairs, and the detailed index is particularly useful for locating the odd pavilion (Futurama), entertainer (Sally Rand), or theme ("Century of Progress"). The only disappointment with this volume is the paucity of photographs and illustrations. Otherwise, this Historical Dictionary is at once a fun browse and a helpful beginning point for students and scholars.-B.J.

Melton, J. Gordon. New Age Encyclopedia. Detroit, Mich.: Gale, 1990. 586p. $\$ 59.50$ (ISBN 0-8103-7159-6).

J. Gordon Melton and the members of the Institute for the Study of American Religion, authors of such notable reference works as the Encyclopedia of American Religions (Guide BB57), have produced a handy, one-volume guide to the various spiritual and social phenomena, personalities, and institutions which the new age has spawned. While previous works on new age movements have been either naive and unscholarly or openly hostile, this New Age Encyclopedia "moves away from the polemical stances taken by evangelical Christians, skeptics, and others to provide a balanced, objective and comprehensive overview of the New Age Movement as well as information about its many ideological and structural components and major leaders" (Introd.). The result is a succinct and unsensational discussion of topics as diverse as Ignatius Donnelly, dolphins, and Dianetics.

The main portion of the Encyclopedia consists of alphabetically-arranged, signed entries on concepts, persons, and organizations which range in length from a paragraph to several pages. Each entry includes at least one bibliographic reference for further information. Many of the topics covered are fairly contemporary (Seth, harmonic convergence, macrobiotics), and often addresses are provided for extant organizations. How- 
ever, special effort is given to the description of the historical context and development of philosophies and phenomena. For example, "channeling" and the use of crystals in magic and healing are both traced back to ancient times.

Preceding the encyclopedia entries is an introductory essay on the origins and growth of the new age movement and a chronology. An appendix lists educational institutions which offer accredited and nonaccredited programs in new age subjects, and an index provides access to persons, topics, and institutions which are discussed within the text of the encyclopedia entries.

A recent trade publication by the same authors, the New Age Almanac (New York: Visible Ink, 1990. 479p.), contains essentially the same information arranged in chapters with one long bibliography in the appendix and no index.

The New Age Encyclopedia should prove useful in almost any library, covering, as it does, topics which are often too obscure, too recent, or too short-lived to be found in most standard reference sources.-B.J.

\section{WOMEN'S STUDIES}

Carter, Sarah. Women's Studies: A Guide to Information Sources. London, New York: Mansell; Jefferson, N.C.: McFarland, 1990. 278p. £35 (ISBN 0-72012058-6). LC 89-39974.

This British guide to women's studies differs from Susan Searing's Introduction to Library Research in Women's Studies (Boulder, Colo.: Westview, 1985) in several ways. It has an international focus and includes many more titles published outside the United States; it only lists works dealing specifically with women; for each topic it lists periodicals, organizations, and resources, in addition to bibliographies, encyclopedias, and indexes. Nearly 1,100 English-language works published between 1978 and 1988 are cited, with some earlier and more recent works included. It is arranged in three main sections: general material (e.g., reference sources, biographical in- formation, and women's studies); Women in the World (subdivided by continent, region, and country); and Special Subjects (thirteen topics including arts and media, education, history, leisure, mythology and religion). A particularly useful feature is the listing of titles under more than one subject, with appropriate annotations ranging from two lines to two paragraphs. Women's Studies is indexed by author, title, and subject and is recommended to libraries supporting graduate research in women's studies or which have very strong international collections.-S.S.

Kahn, Ada P. and Linda Hughey Holt.

The A-Z of Women's Sexuality. New

York: Facts On File, 1990.362p. \$24.95

(ISBN 0-8160-1996-7). LC 89-28211.

This dictionary lists terms related to various aspects of woman's sexual nature, ranging from obstetrics and gynecology to sexual behavior and psychological development. The majority of the work is devoted to the alphabetical entries, which vary from one line to several pages in length. Coverage is broad and includes technical medical terms, proper names, common and slang terms, historical and mythological references, and some social issues. The authors, both with credentials in the health professions, provide factual treatments of even the most controversial topics, such as abortion.

In addition to the dictionary section, a bibliography lists books and journal articles for further reading. This section is divided into broad topics such as "feminist viewpoints," "childbirth," and is arranged alphabetically. Most of the references are from the 1970 s and 1980 s, but few are more recent than 1988 .

The liberal use of cross references in the body of the work is enhanced and expanded by a detailed index which provides access to references within the entries. Although there are some inconsistencies in the cross references and indexing, they are relatively minor. Overall this is a clear presentation of information that will be of interest in most academic libraries.-B.K. 


\section{SOCIOLOGY}

Zollar, Ann Creighton. Adolescent Pregnancy and Parenthood: An Annotated Guide. Reference Books on Family Issues, no. 16; Garland Reference Library of Social Science, no. 523. New York: Garland, 1990. 224p. \$36 (ISBN 0-8240-4295-6). LC 89-25596.

This is a most welcome annotated bibliography of recent psychological and sociological literature on the social problem of adolescent pregnancy and parenthood in the United States. Ann Creighton-Zollar, associate professor of sociology at Virginia Commonwealth University, has selected and organized these materials for novices in the field (student, researcher, or professor), as well as for graduate students in sociology who need to be aware of how various disciplines-social work, public health, nursing, public affairs-deal with this problem.

Because the emphasis is on materials readily accessible to the student, the bibliography has been limited to Englishlanguage books, chapters in books, and periodical articles, the majority of which have been published between 1970 and 1989; there is a final section listing the tape holdings of the Data Archive on Adolescent Pregnancy and Pregnancy Prevention, sponsored by the U.S. Office of Population Affairs. The author's initial search was limited to Sociological Abstracts and Psychological Abstracts, then to a search for the most frequently cited references; this accounts for the heavy preponderance of periodical articles among the 787 citations. There is a detailed subject arrangement comprised of twelve sections, each section subdivided by format, with the sections on "Social Consequences" and "Services" further subdivided into topics such as coping and family support, social costs, family planning, pregnancy prevention, and services for pregnant and parenting teens. There is an author index.

Researchers may question the author's decision to exclude items "expensive to obtain (like dissertations)" or "difficult to obtain (like some govern- ment documents)" (p. xi); librarians may regret the absence of cross- and see-also references (each item is listed only once), and wonder what titles would have been added by a search of Inventory of Marriage and Family Literature (Guide CC216n). But when you are confronted by the question "Why has so little been written on the adolescent father?", you will be pleased to lay that myth to rest by turning to pages $169-85$ of this book.D.K.G.

\section{AFRO-AMERICAN STUDIES}

Black Americans Information Directory 1990/91. Darrin L. Smith, ed. Detroit, Mich.: Gale, 1990. 424p. $\$ 69.50$ (ISBN 0-8103-7443-9, ISSN 1045-8050). LC 90-648616.

"The purpose of the Black American Information Directory (BAID) is to provide a comprehensive source of information on organizations, programs, faculties, publications, and other resources for, and about, Black Americans (Intro.). This first volume is compiled from other Gale publications, including Awards, Honors, and Prizes (Guide CB313), Directories in Print (CH256), Directory of Special Libraries and Information Centers (AB53), Encyclopedia of American Religions (BB57), Encyclopedia of Associations (CA125), Gale Directory of Publications (Ayer's) (AE31), Newsletters in Print (AF30), Publishers Directory (AA355), Research Centers Directory (CA127), and Video Source Book (AA540). The entries are arranged in seventeen chapters, covering topics such as "Colleges and Universities," "Library Collections," and "Radio and Television Stations." A name and keyword index concludes the volume.

While many librarians and readers will find it convenient to have information from such a wide variety of publications in one easy-to-use source, the selection criteria for $B A I D$ seem at times uneven or undefined. For example, in the "Videos" section, many items are included merely because they have one or two black performers (e.g., Lena Horne in "Ziegfeld Follies") rather than because they address any specific African 
American theme or issue. The section on "Black Studies Programs" merely lists colleges and addresses without any description of their offerings or requirements. Librarians may wish to use Black Americans Information Directory as an index or a pointer to reference works which provide more complete descriptive listings, such as Gale's own Negro Almanac: A Reference Work on the African American (5th ed. Detroit, Mich.: Gale, 1989) in which there is considerable overlap in coverage.-B.J.

Rice, Mitchell F. and Woodrow Jones, Jr. Health of Black Americans from Post Reconstruction to Integration, 1871-1960: An Annotated Bibliography of Contemporary Sources. New York: Greenwood, 1990. 206p. \$39.95 (ISBN 0-313-26314-0). LC 89-78161.

This volume, the latest in Greenwood's Bibliographies and Indexes in Afro-American and African Studies, lists 592 citations to contemporary sources which should prove useful to both social and medical historians. The selective time period is deliberate; pre-1871 material is excluded because little was published on this topic before emancipation and reconstruction, and it was only after that time that "blacks began to leave the plantation system where a modicum of health care was provided and ventured into a social order where little or no health care was available to them" (Introd.). Post-1960 publications have been listed in a companion volume, the authors' Black American Health (New York: Greenwood, 1987. 140p.).

The bibliography is preceded by an introductory essay which sketches topics such as sanitation, housing, and working conditions during the period in question. The citations are divided into three main sections by publication date: 1871-1919, 1920-1950, and 1951-1960; entries are arranged alphabetically within each section. Almost all the citations are to articles in medical or health journals, and the majority (about twothirds of the entries) falls into the 19201950 section. The volume concludes with author and title indexes.
Though most of the material cited in Health of Black Americans is quite clinical in nature, it should provide researchers in African-American studies with interesting sources from a perspective outside the humanities and social sciences.-B.J.

\section{GERMANS IN THE U.S.}

Tolzmann, Don Heinrich. Catalog of the German-Americana Collection, University of Cincinnati. Munich and New York: Saur, 1990. 2v. \$215 (ISBN 3-59841241-X). LC 90-175005.

The German-Americana Collection of the University of Cincinnati is one of the largest in the country, containing primary and secondary material relating to German-Americans throughout the United States. The collection is based on the private library of Dr. Heinrick Fick, a nineteenth-century Cincinnati educator, and supplemented by other notable acquisitions. This catalog is the result of a grant to the German-Americana library, which allowed it to index its collections for the first time. The compilers also indexed fifteen important GermanAmerican, nineteenth- and twentiethcentury journals.

It has a classified arrangement, which unfortunately could be more detailed. For example, the sixteen pages listing information on the forty-eighters are arranged alphabetically by author. To find all the material on Carl Schurz, the reader either has to look at every entry or constantly to refer to the index. Nevertheless, this is a welcome supplement to Henry Pochmann's Bibliography of German Culture in American to 1940 (Guide CC331) and Arthur Schultz' German-American Relations and German Culture (Guide CC331a).-M.C.

\section{STATISTICS}

International Directory of Non-Official Statistical Sources. London: Euromonitor, 1990. 155p. $€ 85$ (0-8633-8354-8). LC sn90-39095.

A companion volume to Euromonitor's European Directory of Non-Official Statistical Sources published in 1988, the direc- 
tory focuses on consumer markets, products, and trends; key industrial sectors such as energy, agriculture, construction, and chemicals; and national economic and business trends. Non-official sources are those not connected with central governments or with international governmental bodies such as UN, OECD, EEC, IMF etc.. The major producers of statistics listed in this directory are trade or professional associations, research organizations, trade journals, periodicals, financial institutions, and statistical databank companies. In order to merit inclusion the sources listed must appear at least once every five years.

Major countries covered are Australasia, Canada, India, Japan, and the United States, with limited coverage provided for twenty-six other countries, and some regions. "Limited" ranges from one to ten cited sources-for fourteen of the included countries there is only one source given for non-official statistics. The strength, therefore, is in the coverage of key countries. A separate list of international sources (regardless of provenance) is included that identifies items where coverage is not confined to a single country.

The body of the directory is an alphabetical arrangement by source. Briefly annotated, with information on supplier, the price is indicated for many titles, but not often enough. A subject index and a geographical index of sources are included. The preponderance of key, country sources makes it a largely redundant acquisition in a well-stocked U.S. business library. A smaller library might be put off by the price.-J.C.

\section{A Guide to Latin American and Caribbean}

Census Material: A Bibliography and

Union List. Carole Travis, ed. Boston,

Mass.: Hall, 1990. 739p. \$85 (ISBN 0-

8161-0497-2). LC 89-49739.

This bibliography and union catalog of Latin American statistical sources in the United Kingdom covers "censuses of any kind," not just population censuses. It is arranged by country and then chronologically, with an index by geographic name and topic.
The Guide, a joint enterprise of eighteen people, lists various types of censuses from forty-one countries: population, labor, manufacturing, mining, agricultural products such as olives or coffee. Each country section begins with a general description of the censuses and in some cases cautionary remarks about using them, followed by lists of specific censuses. Some entries have a note describing the contents and special features. General Latin American censuses are included in the appendix. The Select Bibliography lists useful sources from government document catalogs to journal articles.

Each entry is accompanied by one or more location symbols, which lead to university, public and research institute libraries in the U.K. Although it has a limited use as a union catalog for an American researcher, this would be a good addition to a reference collection for Latin American studies.-J.S.

\section{FOREIGN AFFAIRS}

\section{Silverberg, Sanford R. and Bernard}

Reich. United States Foreign Policy and the Middle East/North Africa: A Bibliography of Twentieth-Century Research. Garland Reference Library of Social Science, no. 570. New York: Garland, 1990. 407p. \$50 (ISBN 0-8240-4613-7). LC 89-23452.

Compiled by two academic researchers in the field, the bibliography aims at a comprehensive coverage of the works relating to the U.S. involvement in the region in the twentieth century, especially during the period from World War II to the Reagan administration. The Middle East and North Africa are defined as "the non-Arab states of Israel, Turkey, and Iran and the Arab states of Algeria, Bahrain, Egypt, Iraq, Jordan, Kuwait, Lebanon, Libya, Morocco, North Yemen, Oman, Qatar, Saudi Arabia, South Yemen, Sudan, Syria, Tunisia, and the United Arab Emirates"' (Introd.).

The bibliography contains primarily English-language materials in various forms: books, articles, government documents, master's and doctoral theses, 
which were published through early 1989. Also included are selected materials on earlier American missionary, educational, and philanthropic activities in the Middle East. The items (3,676 in all) are arranged in alphabetical order by author. There is no title index.

Although it is timely, it could have been a much more useful publication in view of recent U.S. involvement in the region. The bibliography is not well served by the subject index, which is an extremely broad topical index. A halfpage list of item numbers without any subdivision under "Israel" or some thirty numbers under "Arab Boycott" would be of small help to the researcher who wants to use this bibliography. If this bibliography, which the editors compiled using Pro-Cite (a bibliographic management program), had been published as a computer-readable bibliography on a diskette rather than in printed form, the indexing would not have been so problematic.-J.S.

\section{SOVIET UNION}

A Guide to Scholarly Resources on the Russian Empire and the Soviet Union in the New York Metropolitan Area. Robert A. Karlowich, comp. Armonk, N.Y.: M.E. Sharpe 1990. \$45 (ISBN 0-87332619-9). LC 89-24314.

The New York metropolitan area is home to one of the country's richest collections of research material for the study of the Russian Empire and the Soviet Union. The collections are housed in a variety of academic and research libraries, museums, scholarly institutes, fraternal and cultural organizations, government bodies, corporations, and held by private individuals. Until now, however, there has been no reference guide [analogous to the Smithsonian Scholar's Guide to Washington (Guide, DC552)] specifically tailored to assisting researchers in coordinating their research. It was with the aim of addressing this need that noted Slavic bibliographic specialist Robert Karlowich was commissioned by the Social Sciences Re- search Council to compile this work. The result of his efforts is an outstanding compendium, one that every library supporting research on Russia and the Soviet Union and many scholars in the field will want to own. In addition, any Russian or Soviet researcher planning to do work in the New York area will certainly want to consult this volume.

The area chosen for coverage extends to a fifty-mile radius of midtown Manhattan, and so includes such important institutions outside the city proper as Princeton University, West Point, and St. Vladimir's Seminary. Descriptions are provided for 153 separate collections (including individual departments within larger research institutions such as the New York Public Library or Columbia University Libraries). The entries, which range from one to several pages in length, provide addresses, telephone numbers, a description of the terms of access, and the facilities available (reading rooms, photocopy machines, etc.), information on the history of the institution, a brief survey of holdings, notes on any special features of the collection, and a listing of any available catalog or finding aid as well as a bibliography of other descriptions of the collection. There is also an excellent name and subject index. The materials covered range widely and include books, manuscripts, recordings, art works, photographs, costumes, and other realia. They document Russian and Soviet history from the Middle Ages to the present and the life of emigré and immigrant communities as well. Represented are institutions as diverse as the New York Public Library, the Museum of Modern Art, the YMCA, the ILGWU, the International Research and Exchanges Board, the New York Life Insurance Co., and at least fifteen private collectors.

At the same time, Karlowich points out, this is but a preliminary survey of resources. Only about half of the institutions originally approached returned the questionnaire supplied to them. As a result, one must still turn, among other things, to Grant and Brown's older and out-of-print Russian Empire and Soviet Union: A Guide to Manuscripts and Archi- 
val Materials in the United States (Guide AB118a). The Karlowich work is the only study to date to focus exclusively on the New York area, and it provides the most up-to-date and accessible information on all of the leading institutions there. A parallel survey of East European resources in the New York area is now underway and should result in the completion of a companion volume late this year or early in 1992.-R.H.S.

\section{de Mowbray, Stephen. Key Facts in Soviet} History. Boston, Mass.: Hall; London: Pinter in assoc. with John Spiers, 1990. In progress. Contents: v.1, 1917 to June 22, 1941. 386p. \$40 (ISBN 08161-1820-5). LC 90-201110.

This work, inspired no doubt by the current upsurge of interest in the USSR, seeks to provide a chronological outline in English of the major events and developments in the history of the Soviet Union, designed largely for the nonspecialist reader. As such, it appears to have no real counterpart and is thus a welcome addition to the reference tools available for Soviet area studies, political science, and history. To date, one of two projected volumes has appeared, covering the period from the revolutions of 1917 to the Soviet entry into World War II. The greatest coverage is naturally given to more easily dated domestic political events and foreign affairs, but pains are taken to cover economic, social, and, to a lesser extent, cultural developments as well.

The work is based largely on Englishlanguage sources and, hence, to a slightly lesser extent, secondary sources, all of which are listed in an extensive bibiliography at the end of the volume. (It should be noted, however, that those sources represent an impressive crosssection of the latest English-language historiography.) The author recognizes the additional difficulty this reliance on secondary literature may pose for the already difficult task of precisely dating the events of Soviet political history, but he argues, convincingly, that the dates offered here are no doubt "accurate enough for most practical purposes" (Introd.). More regrettably, however, Mowbray's intended nonspecialist audience has led him to omit any citations to specific sources at the end of individual entries (although reference is generally made to an author or authors when there is some controversy or speculation surrounding a particular issue).

The work supplies much more than a simple chronicle of events. Admirable care is taken to provide background material in order to explain the significance of many events and even to indicate some outstanding questions of interpretation, so that individual entries can range from one or two lines to two or three pages in length. For this reason, the chronology will probably be most fruitfully used by those who want to read through the pages describing a certain period in order to gain a better sense of the chronological interrelation of developments on various fronts. The work is helpful also for those who might want to zero in quickly on a certain event whose precise date they do not know.

Indexes of personal and geographical names are provided, but nothing more, making it difficult to locate information quickly (for example, on individual party congresses) or to trace developments relating to the peasantry, the army, or the Orthodox Church. For the same reason, the author's useful summaries of economic and other developments that cannot be easily fixed to a single date are lost to a user who does not intend to wade through all the entries relating to a particular time period. Nor is any use made, in a sometimes lengthy text, of any boldfacing or other typographical variation that might help the reader to zero in on a key name or phrase. One can only hope that a subject index (and ideally, a detailed one) will appear at the end of the forthcoming second volume, for the text does a very good job of introducing, in a schematic yet reasonably sophisticated form, the basic events and issues of the history of the Soviet Union.-R.H.S. 


\section{FRANCE}

Biographical Dictionary of French Political Leaders since 1870. David S. Bell, Douglas Johnson, and Peter Morris, eds. New York: Simon \& Schuster, 1990. 463p. \$75 (ISBN 0-13-084690-2). LC $90-9662$.

Where to turn for biographical information in English for French senators, deputies, ministers, political writers, diplomats, journalists, and editors has always been a problem. This is the issue addressed by the Biographical Dictionary of French Political Leaders which aims "to be of use to the many people in many countries who are interested in the past and present of the politics of France and who may not always have a reading command of French" (Pref.). Sponsored by the Association for the Study of Modern and Contemporary France, its members helped select names for inclusion as well as contributed individual biographies; the entries show the care with which this was done. Signed articles of one-and-a-half to three columns describe the career and background of each political leader with an indication of how he was/is regarded by his contemporaries. Each entry ends with a bibliography of articles and books in both French and English (English is the preferred language) with notes to identify a definitive study, to point out the lack of any critical studies, the existence of profiles, or the need to use biographies of specific colleagues.

The index offers entries to political organizations, parties, people cited in other entries, subjects of biographies, pseudonyms, and topics. Appendixes give lists of French presidents, prime ministers, post-war Union leadership, and Fifth Republic party leadership.

Of course this is not going to replace the various Dictionnaire des Parlementaires Français (Guide CJ297-298) but the purpose is entirely different. The Dictionary is intended for English language speakers and for that reason should receive wide use in college and university libraries, as well as in the larger public libraries.-E.M.
Hansen, Arlen J. Expatriate Paris: A Cultural and Literary Guide to Paris of the 1920s. New York: Arcade, 1990. 335p. $\$ 24.95$ (ISBN 1-55970-018-1). LC 896963.

Organized geographically, this guide "offers a mosaic of persons, places, dates, images, incidents, and rumours" (Note to the Reader). Some one thousand addresses of residences, cafes, hotels, galleries, and commercial establishments are presented in clusters within eight major areas of Paris. Entries include information and anecdotes about the people and events associated with each address and about physical qualities of the place itself. Information was gathered from memoirs, biographies, and histories of Paris in the 1920s, as well as contemporary directories. A thirtypage bibliography "lists the major literary works that were composed or published in Paris during the '20s, as well as the expatriate's principal memoirs about the period" (p.277). Nine maps and three indexes (e.g., by person, place or event, and street) facilitate reference use. This guide is informative and entertaining; it would have been even more useful if the sources of each anecdote and entry had been cited.-S.S.

\section{FRANCE-ARCHIVES}

The 1979 legislation on archives and the opening of collections relating to World War II have prompted the publication of new and updated catalogues and a general inventory of research tools. The following is a listing of those guides to the French public archives since that time.

The five-volume État général des fonds (Guide DC161), a detailed survey of the collections in the Archives Nationales, has been recently completed. Four of the six projected volumes of its companion series, L'état des inventaires, have appeared. When completed, it will be a comprehensive list of inventories and other research tools for French public archives as of January 1, 1983, including anything from hand-written registries to printed, analytical catalogs. These two 
series are indispensable tools for historical research in France in addition to the enormous compilation of the catalogs of manuscripts in French public libraries, Catalogue général des manuscrits des bibliothèques publiques de France (Paris: Ministère de l'instruction publique et des beaux arts, 1885-1975) which are, despite the lack of systematic updating, still very useful.

The two series, L'état général des fonds and L'état des inventaires, follow the same organization: major chronological divisions and then "série." There is no general index to the set, but the table of the standard classification system used in the French archives and detailed tables of contents in each volume provide access to the section containing relevant material.

Archives nationales. L'état général des fonds. Paris: Archives nationales, dist. by La Documentation française, 1978-1988. 5 v. Contents: 1: L'Ancien Régime. 1978. 95F (ISBN 2-86000-0208); 2:1789-1940. 1978. 95F (ISBN -0216); 3: Marine et Outre-Mer. 1980. 150F (ISBN -025-9); 4: Fonds divers. 1980. 120F (ISBN -026-7); 5: 1940-1958, Fonds conservé à Paris. 1988. 220F (ISBN -142-5).

This survey is not a catalog which describes every piece in a box, but it is detailed enough to orient a researcher to an appropriate section of a collection. Volume 1 covers the documents which originated from the institutions of the Ancien Régime, papers of aristocratic families, and ecclesiastic archives. Volume 2, of course, describes the archives for the period 1789-1940. Volume 3 lists the archives of the Navy up to 1870 and the Colonial Office documents to 1940.

Volume 4, the most diverse of all volumes, contains the holdings of the Minutier Central des Notaires de Paris, business archives, scholars' papers, maps, microfilms, and audio-visual material. The Minutier Central has been a trove for historians of mentalities. Through the records of civil legal transactions, such as marriage contracts, real property sales, wills, and estate invento- ries, historians have attenpted to analyze quantitatively the thoughts and actions of ordinary people, especially religious beliefs and family relationships. Only documents more than 100 years old can be consulted.

Volume 4 also includes the corrections and additions to volumes 1-3. Volume 5 surveys the collections relating to recent history in the archives located in Paris. (Therefore, it excludes the Centre des archives contemporaines at Fontainebleau.) It also gives a detailed list of the members of the French Cabinet from 1940 to 1959.

Les Archives nationales. L'état des inventaires. Paris: Archives nationales, dist. by La Documentation française, 1985-86. 4 v. Contents: 1. Ancien Régime. 1985. 150F (ISBN 2-86000067-4);2. 1789-1940. To be published. 3. Marine et Outre-Mer. To be published. 4. Fonds divers. 1986. 160F (ISBN -103-4).

L'état des inventaires des Archives départementales, communales et hospitalières....Paris: Archives nationales, 1984. 2v. 390F/set.

Together these two titles are a major revision of the État des inventaires des archives nationales, départementales, communales et hospitalières au ler janvier 1937 and Supplément (1937-1954) (Guide DC162) and describe all inventories as of January 1, 1983, for regional archives as well as the Archives nationales.

The use of terms such as inventaire analytique, répertoire numérique, catalogue, and inventaire sommaire is standardized throughout the series. Together with helpful notes under each item describing the arrangement and indexes, this inventory of inventories would give the prospective archival researcher a good idea of tools available. On some of the inventories, the researcher is expressly warned that they are "difficult to use."

In France, government business extends into greater domains than in the United States, so the reader would find not only documents in politics and national finance but also records relating to theater, fine arts, cinema, and universi- 
ties: Série AJ, for example, contains the archives of the Théâtre de l'Odéon, broadcasting, and music education. A number of private archives are also deposited in the national and departmental archives. Among the Fonds divers, are archives of business firms (Série AQ), scholars' papers (Série AB XIX), newspapers (Série $A R$ ), and family archives (Série AP). The inventory includes catalogs of audio-visual material, oral history, and microforms.

The État des inventaires des Archives départementales has two parts: part I: general tools of research arranged by historical period and subject; and part II: tools of research by department. The set includes a list of laws, statutes, etc., relating to the archives and a list of chief archivists.

France. Ministère des affaires étrangères.

État général des inventaires des Archives diplomatiques. Paris: Imprimerie nationales, 1987. 249p.

Unlike its predecessor, which was compiled mainly as a manual for the archival staff in 1967, this catalog of inventories aims to assist readers by including inventories of the archives of diplomatic and consular stations and records of the French occupation in Germany and Austria. This supplements the two-volume guide published in 1984-85: Les Archives du Ministère des Relations extérieures depuis les origines, histoire et guide suivis d'une étude des sources de l'histoire des Affaires étrangères dans les dépôts parisiens et départementaux.

Guide des Papiers des ministres et secrétaires d'état, de 1871 à 1974. 2d ed. Paris: Archives nationales, 1984. 282p. (ISBN 2-86000-099-2).

This guide to archival material of cabinet members in national, departmental, and private archives is arranged in alphabetical order by name, with short biographical data, location of papers with brief descriptions, catalogs, if any, and terms of access.

Guide des Papiers privés d'époque révolutionnaires. Paris: Archives nationales, 1987. 301p. (ISBN 286000-132-8).
Arranged by location, it covers departmental archives and the Archives nationales-index by name, brief description, call number, and a catalog or index, if available.

\section{L'Administration parisienne à la Veille de la}

Revolution: Délibérations du bureau de la ville de Paris, 1784-1790. Paris: Archives nationales, 1989. 137p. (ISBN 2-86000-149-2).

This is an inventory of the Minutes of the Bureau, Série H(2), 1954-1961.

Documents du Minutier central des notaires de Paris: Inventaires après décès. Paris: Archives nationales, 1982. In progress. Contents: v. 1: 1483-1547, par Madeleine Jurgens. (ISBN 2-86000039-9).

Also available are the catalogs of records in the Minutier on special topics, mainly the arts and literature: Ronsard et ses amis, compiled by Madeleine Jurgens. 1985 (ISBN 2-86000-109-3); Histoire de l'art au XVI siècle, 1540-1600. v. 1-2, 1985-86. 500F (ISBN 2-86000-108-5); Documents du Minutier central concernant les peintres (Paris: SEVPEN, 1969).

Bernard, Gildas. Les familles juives en France: $X V I^{e}$ siècle-1815. Guide des recherches biographiques et genealogiques. Paris: Archives nationales, 1990. 281p. 230F (ISBN 2-86000-167-0).

The most recent addition to biographical and genealogical research. It supplements Les familles protestantes en France: XVI siècle - 1792 (1987.699p.) and Guide des recherches sur l'histoire des familles (1981. 335p.). The last guide treats the population incorporated in the parish records of the Catholic Church.

Les inventaires de Archives nationales de

Paris. Cambridge, Eng.; Alexandria,

Va.: Chadwyck-Healey. Approximately 6,500 Microfiche. $\$ 40,000$ est.

Chadwyck Healey is expanding the scope of its microfiche reprinting of national inventories to include British and French archival guides. The newest covers the Archives Nationales and has just begun. When completed, the 740 inventories will be divided into six sections: pre-1789, modern (1789-1940) and Con- 
temporary (since 1940), private archives, plans, Revolutionary France, and fine arts. The price is prohibitively high. One hopes a library would check the État des inventaires to see if individual indexes most useful to their clientele could be purchased separately.-J.S.

\section{NEW EDITIONS, SUPPLEMENTS, ETC.}

The Chambers Biographical Dictionary (Edinburgh: Chambers, 1990. 1604p.; 1969, Guide AJ31) is published in this country under the title Cambridge Biographical Dictionary (New York: Cambridge Univ. Pr., 1990. 1604p. \$34.50). The contributors are British and the dictionary has a strongly European slant. In this edition the focus is more on the twentieth century, on women, and "personalities from more popular spheres such as sports, media, and jazz" (Pref.). Dropped is the subject index by broad categories, e.g., exploration and geography; the cross-references are retained.

K.G. Saur has issued an index to one of its large microfiche biographical projects: Indice biográfico de España, Portugal e Iberoamérica/Spanish, Portuguese and Latin American Biographical Index, edited by Victor Herrero Mediavilla and Lolita Rosa Aguayo Nayle (München: Saur, 1990. 4v. 1429p. 960DM). The Indice is a list of about 200,000 names included in the microfiche set, Archivo Biográfico de España, Portugal e Iberoamérica, and cites the biographical dictionary from which the entry came, as well as the position on the microfiche where the entry is reprinted. Also included are birth and death dates and occupation to make identification easier. The people selected for coverage lived between the seventeenth century and the early years of the twentieth century. The Indice is a useful gateway to one's collection of Spanish and Portuguese biographical dictionaries even if the library has not purchased the microfiche set.

The eleven years from June 30, 1976 to June 30,1987 , saw the deaths of some of the great librarians-Jesse Shera, Constance M. Winchell, Louis Round Wil- son, Maurice Tauber, to name but a few. Fifty-one such library leaders are treated in the Supplement to the Dictionary of American Library Biography, edited by Wayne A. Wiegand (Englewood, Colo: Libraries Unlimited, 1990. 184p. \$45). About one-third of the biographies have been published previously in the Journal of Library History (now Libraries and Culture). The Supplement follows the pattern set by the original edition (1978. Guide AB102): alphabetical arrangement, extensive survey of the career, and a concluding biblography for each, listing obituaries and primary and secondary sources.

The Biographical Directory of the United States Executive Branch (New York: Greenwood, 1990.567p. \$75. 1977, Guide CJ122) is updated through 1989 for the Reagan and Bush administrations. Besides the new entries, older ones are updated as necessary.

Treatment of another part of the Federal government has also been updated: Congressional Quarterly's Guide to the U.S. Supreme Court, by Elder Witt, 2d ed. (Washington: Congressional Quarterly, 1990. 1060p. \$149; 1st ed. 1979; Guide CK141) The arrangement is the same though many of the articles have been expanded or added to reflect events and cases of the last ten years, e.g., affirmative action, the separation of powers. The subject index is now more detailed, and there is a complete case index.

David Mort has updated his Sources of Unofficial UK Statistics (2d ed., Aldershot, Hants., Brookfield, Vt., Gower, [1990]. 413p. £45; 1st ed. 1985). In this edition, "1077 statistical titles and services produced by over 600 organizations are included. . . [with] the information on the sources obtained between March and September 1988" (Introd.).

Die Frauenfrage in Deutschland has a murky publishing history. The first volume covered 1790-1930, was edited by Hans Sveistrup and Agnes von ZahnHarnack, and published in 1934. Volumes 2-8 covered publications 1931-1976 and were published by the Deutscher Akademikerinnenbund. With 
v.8, K.G. Saur took over the publication and in 1982 issued v.10, a cumulation of v.2-9, which brings coverage of publications on women in Germany to 1980. Following this event Saur began a new series (n.F.) which is an annual bibliography for each year beginning with 1981 . The latest to appear is n.F. 4, for 1985 (München: Saur, 1990. 413p. 78DM) which lists almost 4,500 essays, books, and articles. This is a comprehensive compilation and one hopes the schedule of publication will accelerate.

Granger's Index to Poetry (Guide BD302) has been completely revised and published in a ninth edition under the title The Columbia Granger's Index to Poetry (New York: Columbia Univ. Pr., 1990. 2082p. \$175), edited by Edith P. Hazen and Deborah J. Fryer. The Index includes 150 new anthologies published up to June 30, 1989, and more than 100,000 poems. Accompanying this new edition is The Columbia Granger's Guide to Poetry Anthologies, compiled by William and Linda Sternberg Katz (New York: Columbia Univ. Pr., 1991. 231p. \$45). The compilers have taken all the anthologies included in the ninth edition and listed them by the type of poetry published in each volume, e.g., Latin American poetry, political poetry, provided a complete bibliograpical citation, and an evaluative annotation. Finally there is a two-page list of highly recommended anthologies.

The literature on proverbs has found a significant bibliographer in Wolfgang Mieder, who compiled International Proverb Scholarship: An Annotated Bibliography (1982, Guide BD175). Now comes a supplement of almost 900 entries for those items missed in the earlier work: International Proverb Scholarship... Supplement I: 1800-1981 (New York: Garland, 1990. 436p. \$54. Garland Folklore Bibliography no. 15. Garland Reference Library of the Humanities no. 1230). Mieder even learned Russian to complete the coverage in that language. A second supplement is planned to cover entries for 1982-1991.

The Dictionary of Literary Biography (Detroit, Mich.: Gale, 1990. ca.
$\$ 103 /$ each. Guide BD416) is in good health and issuing new volumes at an enormous rate: v. 92, Canadian Writers, 1890-1920, ed. W.H. New (472p.); v. 93, British Romantic Poets, 1789-1832, 1st series, ed. John R. Greenfield (423p.); v. 94, German Writers in the Age of Goethe: Sturm und Drang to Classicism, ed. James Hardin and Christoph E. Schweitzer (413p.); v. 95, Eighteenth-Century British Poets, 1st series, ed. John Sitter (436p.); v. 96, British Romantic Poets, 1789-1832, 2nd series, ed. John R. Greenfield (428p.); v. 97, German Writers from the Enlightenment to Sturm und Drang, 17201764 , ed. James Hardin and Christoph E. Schweitzer (399p.); v. 98, Modern British Essayists, 1st series, ed. Robert Beum (421p.).

Shakespeare: A Bibliographical Guide is a collection of bibliographical essays written by scholars, edited by Stanley Wells (1973; Guide BD710). The new edition is much revised, still aiming "to provide a selectively critical guide to the best in Shakespeare scholarship and criticism" (Introd.), and adding an additional chapter, "Critical Developments: Cultural Materialism, Feminism and Gender Critique and New Historicism." There is still no index (Oxford: Clarendon, 1990. 431p. £35).

Some supplementary volumes can be announced: Norman Kiell, Psychoanalysis, Psychology and Literature (Metuchen, N.J.: Scarecrow, 1990. 587p. \$67.50) adds coverage, mostly $1980-1987$, to his earlier compilation (Guide BD11). The Index to Plays in Periodicals 1977-1987, compiled by Dean Keller (Metuchen, N.J.: Scarecrow, 1990, 391p. \$42.50) supplements the 1979 edition (Guide BD212) by adding 4,605 plays in 104 periodicals. The same journals are analyzed as in the older work, if they are still being published, and several new ones are added. The third supplement to English Novel Explication, compiled by Christian J. W. Kloesel (Hamden, Conn.: Shoe String Pr., 1990. 351p. \$55; Guide BD629) lists criticism published from 1986 through the first half of 1989 , with a few earlier items.

The International Dictionary of Films and Film-Makers (1984-1987. 5v.) is being 
revised, updated, and much expanded by Nicholas Thomas. Volume 1, Films, has just appeared (Chicago: St. James, 1990. 1105p. \$95). The number of pages has doubled, stills have been added, bibliographies updated, there are $150 \mathrm{com}$ pletely new entries, and the listing of films by director is also new.

In order to recognize Black performing artists in film, television, radio, theatre, dance, and musical performance, the Directory of Blacks in the Performing Arts (1978), compiled by Edward Mapp, gives for each performer a short biography emphasizing information about the career. Also included is a Directory of Organizations. Now a second edition is available (Metuchen, N.J.: Scarecrow, 1990. 594p. \$57.50) which updates the entries in the first edition and adds 300 new entries. The Bibliography is much revised and updated.

As work progressed on the Thesaurus Linguae Graeca database, guides to indicate which Greek authors were included and which editions were used were published in 1977 to a small circulation, followed by a second edition in 1986 and now is again revised and expanded for a third edition, Thesaurus Linguae Graeca Canon of Greek Authors and Works (New York: Oxford Univ. Pr., 1990. 471p. \$39.95). The compilers, Lucy Berkowitz and Karl A. Squitier, have completed the listings for parts I-III, Greek authors up to $600 \mathrm{AD}$, and have included representative Greek authors, 600-1453, selected by the TLG for coverage because they are important sources for quotations of earlier authors, because they compiled scholia to authors of the classical period, or because they are authors of major Byzantine historiography and chronography (the important Byzantine chronicles are cited).

Two new continuations for the arts: Bibliography of American Folk Art for the Year 1988, compiled by Eugene P. Sheehy and Rita G. Keckeissen (New York: Museum of American Folk Art, 1990. 38p.) to cover publications for 1988 and a few for 1987 inadvertantly omitted. Volume 2 of The Index of Paintings Sold in the British Isles during the Nineteenth Century covers some 476 transactions which occurred during the years 1806-1810 (Santa Barbara, Calif.: ABC-Clio, 1990. 2v. \$195).

Alan Meckler and Ruth McMullin compiled Oral History Collections (Guide DB63) to describe oral history projects by listing, with brief descriptions, persons interviewed or prominently mentioned in an interview (with an occasional subject entry). Now Meckler has published the Oral History Index: An International Directory of Oral History Interviews (Westport, Conn.: Meckler, 1990.434p. \$145) to expand on the initial effort. Based on responses to questionnaires, the volume is an "alphabetical index to over 30,000 oral history transcripts held at nearly 400 oral history centers in the United States, Canada, Great Britain, and Israel" (Introd.). It still has no subject index.

The Cultural Atlas of Russia, by R. R. Milner-Gulland (New York: Facts On File, 1989. 240p. \$40) is the same as the Atlas of Russia and the Soviet Union (Oxford: Phaidon, 1989. 240p. £19.50) even though nothing is said in either volume to alert one to this fact.

Facts On File has published another atlas with a slightly different problem. Atlas of American History, compiled by Robert H. Ferrell and Richard Natkiel (New York: Facts On File, 1987. 192p.) is a typical historical atlas combining pictures, photographs, maps, and text. This atlas is now reissued (1990. \$27.95) with a banner on the dust wrapper announcing "updated for 1990." It has been updated with the addition of one map and graph showing 1988 election results and with the addition of Bush's name to the list of U.S. presidents. 